\title{
Disrupting Ignorance and Settler Identities: The Challenges of Preparing Beginning Teachers for Treaty Education
}

\author{
Jennifer A. Tupper \\ University of Regina
}

\section{Author Note}

This research project would not have been possible without the financial support of the President's/SSHRC Research Fund at the University of Regina, and the work of graduate student research assistant, Maureen Thompson. A version of this article was presented at the Canadian Society for Studies in Education Annual Conference, Fredericton, New Brunswick, May 2011.

\begin{abstract}
In the fall of 2008, the Provincial Government of Saskatchewan announced mandatory treaty education for all students in K-12 schooling. Given the foundational importance of treaties and the treaty relationship to Canada, and ongoing reconciliation efforts with First Nations people, this initiative is to be celebrated. However, a central concern exists regarding the implementation of treaty education in Saskatchewan schools. To that end, this paper discusses research, with 348 predominately white, teacher education candidates at the University of Regina, regarding their knowledge, (mis)understandings, and experiences with treaty education, in both grade school and university contexts. Using critical race theory as a lens through which to conceptualize and make sense of the research, along with theories of ignorance as an epistemological exercise, the paper illustrates the imperative of enacting treaty education given (white) settler students struggles(and refusals) to connect their own social and economic privileges to treaties.
\end{abstract}

Keywords: Treaty education; critical race theory; curriculum 


\section{Disrupting Ignorance and Settler Identities: The Challenges of Preparing Beginning Teachers for Treaty Education}

In his book, We Are All Treaty People: Prairie Essays, Roger Epp (2008) argues that if Canadians are to engage in reconciliation with First Nations peoples, there must be rethinking of the history of the country. In part, this requires dismantling the myth of an empty land, in which First Nations peoples are rendered invisible (Furniss, 1999), centering the historical perspectives and experiences of First Nations people in light of colonization, and deconstructing the ways in which particular narratives of Canadian history underwrite the way many Canadians are able to think about their country and themselves as citizens. An essential aspect of working toward reconciliation requires educating about treaties and the treaty relationship between First Nations people and the Government of Canada. J.R. Miller (2009) writes that treaties are one of the "paradoxes of Canadian history. Although they have been an important feature of the country since the earliest days... relatively few Canadians understand what they are or the role they have played in the country's past” (p.3). Treaties between the Canadian Government and First Nations people are foundational to the "story" of Canada, yet this story is largely absent in the narrative of the past that students learn in schools as part of officially sanctioned curriculum. Thus, schools and curriculum are implicated in "forgetting” certain aspects of Canada's past as they function to socialize young people into dominant knowledge systems. Dion (2009) argues, "rendering non-Aboriginal people cognizant of our stories is a crucial first step in establishing fertile ground on which to cultivate an equitable relationship....Stories that dominant Canadian history reflect an unwillingness and inability to come to terms with the reality of Canada's relationship with Aboriginal people” (p. 4-5). Schools, teachers, and curricula must play a central role in helping students understand the foundational importance of treaties to the Canadian nation.

In the fall of 2008, the provincial government of Saskatchewan made mandatory treaty education for all students, in all grades, and in all subject areas. This mandate came after years of effort on the part of the Office of the Treaty Commissioner (OTC), to support and facilitate the teaching of treaties in Saskatchewan classrooms. To be clear, this mandate is not just teaching the "facts" of the numbered treaties; rather, it is about teaching through Indigenous worldviews and exploring the historical and contemporary relationship between First Nations and settlers. It recognizes the unique position of Métis people in relationship to treaties and the unique context of the Dakotas and Lakotas in Canada, specifically in the region of Saskatchewan covered by Treaty 4, and their continued sovereign relationship with the Crown. From the OTC's perspective, treaty education is about revealing colonial and racial practices that remain prevalent in Saskatchewan. Treaty education is anti-racist education (OTC, 2008).

Since the announcement of the mandate, the OTC has created numerous resources for teacher use that support treaty education, including the creation of Treaty Essential Learnings (TELS). The TELS make explicit what students should know and understand about treaties, the treaty relationship, the historical context of treaties, First Nations' worldviews, symbolism in treaty making, and contemporary treaty issues (Office of the Treaty Commissioner, 2008). The corresponding resources include the voices and experiences of First Nations people in Saskatchewan, primary source documents, and pedagogical approaches that incorporate First Nations' knowledge and perspectives. Prior to the announcement of mandatory treaty education, 
and despite the efforts of the OTC to support teachers, there was not widespread attention to treaty education in schools (Cappello \& Tupper, 2006; Tupper \& Cappello, 2008). While the legislation of treaty education in Saskatchewan is to be celebrated, especially because this is a province entirely ceded through treaties, a central concern exists regarding implementation.

Two teacher education programs in the province, one at the University of Saskatchewan in Treaty 6 territory, and one at the University of Regina, in Treaty 4 territory, must be implicated in supporting preservice and in-service teachers to meaningfully enact the mandate for treaty education. For faculty members in both institutions, critical engagement with the foundational importance of treaties and the treaty relationship, thereby helping students to "read" the history of Canada and their own identities as Canadians differently, is paramount. However, to be effective in this project, some sense of the assumptions, beliefs, and understandings that students bring with them to teacher education spaces is required. To that end, this paper focuses on research conducted with 348 undergraduate, preservice teacher candidates at the University of Regina in the winter semester, 2010. The research study explored students' experiences with treaty education in K-12 education, their experiences with treaty education in university classes, particularly their education classes, their knowledge and understanding of treaties and the treaty relationship, and their concerns about implementing treaty education in their own classrooms.

Necessary to this study is an account of the role of curriculum in mediating how students are able to think about the history of this province and themselves as settler-citizens of this province (Battiste \& Semaganis, 2002; Tupper \& Cappello, 2008). Consideration is given to the relationship between curriculum, racism, privilege, identity, and dominance (Apple, 1990, 1996; Carr \& Lund, 2007; Dion, 2009; Donald, 2009; Earick, 2009; Rains, 2006; Schick \& St. Denis, 2005; Tupper \& Cappello, 2008; Willinsky, 1998). The study is attentive to the need for those in positions of dominance to be accountable for ongoing discrimination (St. Denis, 2007). Drawing on critical race theory (Chandler, 2010; Dixson \& Rousseau, 2006a, 2006b; Earick, 2009; Gillborn, 2006; Kailin, 2002; Ladson Billings, 1998; Parker, 1998), as well as the work of scholars who articulate ignorance as an epistemological stance (Bailey, 2007; Martin Alcoff, 2007; Mills, 2007; Sullivan \& Tuana, 2007), this paper argues that school curriculum (and in some instances, the curriculum of teacher education) reinforces settler identities and students' ignorance of how these identities have been normalized over time. It argues that treaty education is a necessary counter story to the dominant narrative of Canadian history, and as such, essential to unsettling settler identities.

Treaty education also offers possibilities for the project of reconciliation between First Nations peoples and settlers. The data from the research project reveals that, despite the efforts of the Office of the Treaty Commissioner over the last two decades, and the provincial mandate for treaty education, preservice teachers' knowledge and understandings of treaties and the treaty relationship is distressingly limited. Further, this paper argues that many of the preservice teachers who participated in the research employ a form of strategic ignorance (Bailey, 2007) as they seek to divest themselves of the responsibility for meaningfully enacting the mandate in their own classrooms. Their responses to anecdotal survey questions are illustrative of settler identities and the concern articulated by Miller (2009) that few Canadians know much about treaties despite their foundational importance to the Canadian nation. Finally, the ease with 
which many of the students reproduce treaty misunderstandings speaks to larger issues of racism and white ignorance (Mills, 2007), and will be explored more fully throughout this paper.

\section{The Curricular Story}

At a simplistic level, curriculum privileges certain content over others: Some material gets included and other material gets left out. Necessarily, curricula are limited and therefore give preferential treatment to certain visions/content/stories over others (Dion, 2009; Donald, 2009; Loewen, 2007; Pinar, 2004; Tupper \& Cappello, 2008). At a more complex level, curricula reproduce dominant knowledge systems through the collective story students are told about "our past, our present and our future" (Grumet, 1981, p. 115). Often, these stories take the form of what Furniss (1999) describes as the "frontier myth of Canadian history,"

a historical epistemology consisting of a set of narratives, themes, metaphors, and symbols that has emerged within the context of North American colonization that continues to define the dominant modes of historical consciousness among the general public, and that various individuals draw upon to construct understandings of the past and the present, of contemporary identities, and of relationships with Aboriginal peoples. (p. 54)

In Canada, "histories commemorating the arrival of early explorers, settlers, missionaries and industries in the remote regions of Canada continue to constitute the master narratives of Canadian nationalism” (Furniss, 1999, p. 53). Wright (2008) maintains "the mythic history [Canadians] have all soaked up describes the land as a 'virgin wilderness' or a 'primaeval forest' inhabited by only a handful of 'wild men' or 'savages'” (p. 48). Legitimate Canadian history begins with the arrival of the Europeans and in Western Canada; it begins with colonization and settling the land. So, rather than understanding the history of European settlement as one of invasion of the land, made possible by the signing of the numbered treaties in the first place, students come to read the "foundational" story of Canada as the resilience and strength of the pioneer homesteader in the face of adversity.

Historically, curricula have served the purposes of empire through social engineering (Apple, 1990; Chambers, 2006). Around the time of Confederation, for example, the Federal Government saw schooling as "a vital part of the plan for the transition of First Nation children towards inevitable assimilation. . . . First Nation children were to be taught . . . the skills of citizenship in the style of the British Canadian” (Littlejohn, 2006, p. 66). Similarly, children of European "settlers" were to be taught the glories of the empire and the same skills of citizenship outside of the necessary partnership with First Nations people essential to European success in the new world (Ralston Saul, 2008). Grant and Gillespie (1993) cite work done in the province of Manitoba to reveal common biases found in curriculum, including bias by omission, bias by defamation, and bias by obliteration. These forms of bias contribute to the various forms of colonization affecting Indigenous students (Castagno \& McKinley Jones Brayboy, 2008). They also contribute to the ways in which settler students read (and racialize) the story of the province and the county in which they live and their relationships with First Nations peoples. 


\section{Curriculum as Counter-Story}

Critical race theorists recognize race and racism as two vital features ingrained within North American society (Bell, 1987; Crenshaw, Gotanda, Peller, \& Thomas, 1995; Crosland Nebeker, 1998; Delgado, 1989 \& 1990; Delgado \& Stefancic, 2001; Howard, 2003; LadsonBillings, 1998; Leonardo, 2005; Parker \& Lynn, 2002; Solórzano \& Yosso, 2002, 2009; Tate, 1997, 1999). In fact, they argue that race and racism are so interwoven into the systems and dominant discourses of our society they appear natural and normal (Ladson-Billings, 1998; Marx \& Pennington, 2003). While critical race theory emerged in the field of legal studies, it offers "great potential to improve educational studies" (Crosland Nebeker, 1998, p. 26). More specifically, critical race theory sees school curriculum as continually reinforcing racialization through "distortions, omissions, and stereotypes" (Ladson-Billings, 1998, p.18). To counteract the role of curriculum in sustaining dominance and privilege, critical race theory uses voice and stories to reveal types of discrimination that are implicit in curriculum when only certain content and perspectives are included (Dixson \& Rousseau, 2006a; Slorózano \& Yosso, 2009). Voice scholarship draws attention to the importance of the individual and communal experiences of "people of color as sources of knowledge" in education (Dixson \& Rousseau, 2006b, p. 35). In the context of treaty education, the TELS make explicit the knowledge and experiences of First Nations people along with their relationships to white settler society. Further, by telling counter stories, it is hoped that a process of adjustment in dominant belief systems and categories will begin (Delgado \& Stefancic, 2001). Treaty education is a counter story as it offers possibilities for settler students to understand how curricular stories of the history of Saskatchewan came to be representative and how other stories were dismissed (Tupper \& Cappello, 2008), while critical race theory more broadly provides a lens through which to read the responses, knowledge and understandings of preservice teachers to the mandate for treaty education.

\section{Surveying Preservice Teachers}

As stated previously, teacher education must be implicated in not only supporting the mandate for treaty education, but also in disrupting colonial narratives and settler identities that students bring with them to undergraduate spaces. It is, thus, important to explicate preservice teachers' understandings and experiences of treaties and the treaty relationship. To that end, 348 students enrolled in the Faculty of Education at the University of Regina consented to anonymously respond to questionnaires. Of these 348 students, 39 cases had to be deleted because of excessive missing data (more than 10\%). Students were given approximately 30 minutes of class time to complete the surveys. For the purposes of this discussion, attention is given to the four anecdotal questions students answered:

1. Describe your experiences with Treaty Education when you were a student in the K-12 system.

2. At this point in your teacher education program, in what ways and in what contexts have you been prepared to implement treaty education in schools?

3. Explain who you think benefits from treaties.

4. Explain the contemporary relevance of treaties. 
Using inductive thematic analysis (Boyatzis, 1998; Creswell, 2005; Fereday \& Muir-Cochrane, 2006; Schumacher \& McMillan, 1993), responses to these questions were coded by researchers for commonly occurring themes and organized into corresponding categories which will be discussed in detail in the sections that follow. This process required an initial reading of all responses to each question in which reoccurring words or ideas were noted. Next, the responses were analyzed line by line to facilitate a microanalysis of the data. Items were then organized based on their similarities into larger categories and the data was revisited to ensure that all items were appropriately categorized. Finally, through the process of axial coding, the final themes reported in this paper were constructed.

In addition to the anecdotal questions, students were asked to provide demographic information including their age, gender, the high school they attended, social science courses they took in high school (history, social studies, native studies, or a combination of these), their year in the teacher education program, and their focus of study within the program (elementary, secondary, middle years, arts education, BAC elementary, BAC secondary). The largest number of students surveyed , 176, were in the first year of their program, with 32 in their second year, 56 in their third year, 24 in their fourth year, and 19 in an after degree program. There were 286 students who self-identified as white, while three self-identified as Asian, seven as Aboriginal, one as South Asian, two as African Canadian, and one as Hispanic. Seven students chose not to self-identify by leaving the question blank. Based on these numbers, it is apparent that the majority of students enrolled in the Faculty of Education are white settler students. Sixty-eight percent of the students had completed or were in the process of completing an Indigenous Studies course outside the Faculty of Education, while $24 \%$ of the students had not yet taken this course. Eight percent of student respondents chose not to indicate whether they had or had not taken Indigenous Studies. Survey responses also revealed that the majority of students, $85 \%$, had not taken a Native Studies class in high school, with only $15 \%$ of students indicating they had taken one or more Native Studies classes.

\section{Experiences With Treaty Education in K-12 Schooling}

Twenty-seven percent of student respondents indicated that they had no experiences with treaty education in their K-12 schooling, while $10 \%$ articulated no memory of learning about treaties throughout their schooling. Another $27 \%$ of students suggested they had minimal encounters with treaty education over their 12 years of education. Eight percent of students responded that they remembered learning about treaties and First Nations people more broadly in their high school social studies and/or history classes. Six percent named Native Studies classes as a space where they encountered treaty education in school. Thirteen percent of students suggested that they had no encounter with treaty education until their senior year in high school, and $7 \%$ of students wrote that they had quite a bit of experience with treaty education while attending grade school. That the majority of students surveyed (64\%) cited limited or no experience with treaty education is troubling in light of the efforts of the OTC to support teachers in treaty education. However, given the concerns cited earlier in this paper regarding the lack of knowledge Canadians have about treaties despite their foundational importance and the role of curriculum in advancing dominant knowledge systems despite the mandate for treaty education, these percentages are not surprising. 
Along with these numbers, anonymous comments offered by students regarding their experiences with treaty education provide insight into the ongoing challenges of reconciliation with First Nations people and the continuing production of settler identities amongst Saskatchewan students. While not all students expressed overtly racist thinking, the comments that follow were selected to underline the reality of racism in Saskatchewan and within teacher education spaces:

"Went to treaty 4 every year: the crime rate in town increased severely for that weekend and extra police were brought in (coincidence?).” (Student 154, Survey, February 2010)

"It was fairly interesting the first couple of years, but I became annoyed with the constant "First Nations and Treaty" subjects, units, and classes." (Student 168, Survey, February 2010)

"It really flew under the radar. There was no mention of treaties in my social studies classes (or at least none that I can recall). There was a First Nations class available, but the only students that took that class were Aboriginal.” (Student 197, Survey, February 2010)

In the first comment, the student is articulating a belief that First Nations peoples are deviant members of society, and as such, their increased presence would require extra policing. In the second comment, the respondent suggests that once the novelty of learning about First Nations people and treaties wears off, the content becomes an annoyance, something to resent rather than embrace for its significance and meaningfulness. The third comment speaks to an implicit belief and more explicit practice in Saskatchewan schools; First Nations content and/or classes are for First Nations and Aboriginal students.

These comments made by some of the preservice teachers in this study regarding treaty education can partially be understood through the lens of critical race theory. Omi and Winant (1994) argue that attention must be given to ways that race and racism are deeply embedded within the framework of society. While their work focuses on the American context of race and racism, it is applicable in the Canadian context as well. The students' comments, the narratives revealed by these comments, along with the lack of experiences with treaty education in K-12 schooling speak to the power of whiteness and of privilege in shaping identities. Further, the ideology of racism "creates, maintains, and justifies the use of a 'master narrative' in storytelling” (Solorzano \& Yoss, 2009, p. 134) and it is this master narrative of the nation that underlies the students' responses to the survey question.

\section{Who Benefits From Treaties?}

In their responses to the question of who benefits from treaties, $40 \%$ of students indicated that everyone does. Eleven percent indicated that everyone benefits, but more so government, and $8 \%$ of students indicated that everyone does, but more so First Nations people. Fourteen percent of students answered that the government benefits from the signing of the numbered treaties, whereas $19 \%$ of students responded that First Nations people have been the main beneficiaries of treaties. Four percent of students believed that no one has benefitted from 
treaties, and 3\% expressed uncertainty as to who benefits. Again, because the surveys were completed anonymously, students felt at liberty to offer further insight regarding the beneficiaries of treaties, including the following responses:

"First Nations people do I believe. They are the ones that have treaties and you are only able to get one if you are First Nations.” (Student 06, Survey, February 2010)

"I think that both Aboriginal and European people benefit from treaties, however, according to the indoctrination of Indigenous 100, the Aboriginal people not only do not benefit, but they are also deterred by the treaties.” (Student 291, Survey, February 2010)

"Of course there were originally more benefits for the newcomers, the tables have turned and now the Indigenous people are riding on the benefits. Not only that but taking advantage of the system by not having to pay for certain things (like University)." (Student 306, Survey, February 2010)

The belief articulated by many of the students that First Nations people are the greater beneficiaries of treaties is necessary to the maintenance of settler identities. Having said that, there were some students who responded that the Government was the greater beneficiary, though in several cases this statement was followed by a caveat that stated they were not sure why. Perhaps they had learned this ("were indoctrinated") in their Indigenous Studies classes, but their inability to elaborate on their understanding must be viewed as problematic. Superficial understanding, the ability to say it, is not necessarily disruptive to settler identities, nor does it make visible the ongoing racism experienced by First Nations and Aboriginal people in Saskatchewan. Similarly, many of the students that attributed treaty benefits to everyone struggled to explain why in their responses. Some students explicitly offered up the phrase "We are all treaty people" used by the Office of the Treaty Commissioner in their televised public awareness campaign, while such a statement was implicit in many other responses. These responses might be read as an effort to posit all citizens of Saskatchewan as equal - we are after all, "all treaty people." If this is how students have taken up the mantra offered by the OTC, then they have little need to consider the ways in which the ongoing racialization of First Nations people by white settlers perpetuates conditions of oppression that reinforce inequality. Nor do they need to consider how their ongoing social and economic privileges as white settlers are directly tied to the signing of the numbered treaties. "We are all treaty people" becomes a feel good phrase to employ in the service of superficial treaty education.

\section{The Contemporary Relevance of Treaties}

When asked to comment on their understanding of the contemporary relevance of treaties, $23 \%$ of students chose to leave the question blank. Two percent answered that treaties held no contemporary relevance, while $11 \%$ were unsure. Nine percent of preservice teachers indicated that the only contemporary relevance was to teach students about the past, while $16 \%$ suggested that they held relevance only for First Nations people in terms of their rights, benefits, protection and opportunities. Fourteen percent of students indicated that treaties were relevant today because they were meant to last forever and $10 \%$ indicated that the relevance was with respect to the relationship between First Nations and non First Nations people. Only 11\% of 
students articulated that the contemporary relevance of treaties is as educative tools to help combat racism, stereotypes and inequity experienced by First Nations people. And while this may be the case, the contemporary relevance extends beyond such a use. Again, several student comments are used to further illustrate students' perceptions / knowledge of the contemporary relevance of treaties to the people of Saskatchewan and Canada.

"It is relevant to Aboriginal people due to the fact that it teaches them of their heritage but I believe that it is quite unfair to force such education upon people of non-aboriginal decent [sic] who have no interest in such things such as myself." (Student 64, Survey, February 2010)

"In today's society they are not addressed much but the First Nations people who use them as a way to get what they want and change to fit their needs." (Student 143, Survey, February 2010)

"I do not feel they are of contemporary relevance in the least and are targeted to benefit First Nations people only. I feel they should be redone and brought up to date.” (Student 161, Survey, February 2010)

"Fuel for Political [sic] correctness debates and other such gong shows." (Student 195, Survey, February 2010)

"The signed agreements are relevant today and influence how First Nations live today." (Student 345, Survey, February 2010)

The overall responses of students to this question, along with the comments included above are demonstrative of a widespread lack of understanding regarding the ongoing importance of the numbered treaties to all citizens of Saskatchewan. Largely, students do not see themselves as direct beneficiaries of the treaties, though their economic and social privileges may be directly traced to them. Settler identities are protected when students continue to (mis)understand the significance of treaties outside of their own privileges. Assigning relevance only to First Nations signatories again belies the foundational importance of treaties to all Canadians and makes more challenging processes of reconciliation. Upon initial reading, the last comment above may appear more insightful; however, it still fails to articulate the influence of treaties on the contemporary lives of settler populations. If these students, who are preparing to become teachers of Saskatchewan's young people, are ignorant of treaties as this research suggests, and worse, perpetuate racist thinking toward First Nations people, as may be inferred from many of their comments, then what hope exists for reconciliation?

\section{Preparation for Treaty Education Within the Teacher Education Program}

In describing their preparation for implementing treaty education through their teacher education program, $20 \%$ of students indicated they had no preparation, while $15 \%$ wrote that they had limited preparation and do not feel competent to enact the mandate. Five percent of students indicated that they had some exposure to treaty education through their required core studies courses, especially Core Studies 110 Self and Other in Education. Eight percent of 
students had participated in the one-day Treaty Workshop facilitated by the OTC, while 4\% had some preparation in their subject area classes, the most often cited being social studies and English methods courses. Twenty percent of preservice teachers acknowledged preparation through their required Indigenous Studies classes outside of the Faculty of Education, and 16\% noted that they had a variety of courses and experiences in preparation for treaty education. Seven percent of students answered that they knew they had to teach treaties in their own classrooms, but no one had told them how to do this. This concern was present throughout student comments, regardless of where the responses are situated in the organization of the data. Some specific comments shed further light on students' response to this question:

"I have learned very little about implementing treaty ed.[sic] I have mostly learned that we are to do it, but not an understanding for each treaty, their significance, and how to implement them.” (Student 54, Survey, February 2010)

“I feel lost in how to implement it.” (Student 228, Survey, February 2010).

"Honestly, I feel like Aboriginal education is shoved down our throats at every opportunity, but no one is ever clear on how to actually teach it. I know a lot about it, but I'm afraid to fail miserably when I teach it.” (Student 238, Survey, February 2010)

First, these findings indicate that there is an imperative within teacher education to more intentionally and systematically work to support the mandate for treaty education. It is not enough to assume that Indigenous studies classes, or certain subject area classes are sufficient in preparing preservice teachers for meaningfully enacting treaty education in their own classrooms. Rather, faculty need to find ways to integrate knowledge and understanding of treaties and the treaty relationship into all core studies courses, subject area curriculum classes, and methods courses across programs. To ignore the data and the corresponding role that faculty members and the Faculty of Education must play in supporting treaty education is to remain complicit in ongoing processes of colonization and the perpetuation of settler identities.

Students' concerns that they do not know "how" to implement treaty education are also worthy of further exploration. Given that these students are enrolled in a teacher education program and have to a lesser or greater extent, depending upon their year in the program, engaged with notions of pedagogy and methodology, then the concern seems to be misplaced. If, for example, students have studied inquiry learning, then aspects of treaty education could be implemented using this approach. Or, if students have engaged in project-based learning, then again, this method might be used as a means of implementing treaty education. Most school divisions in the province also have an Elder in Residence program. This program is intended to provide supports to in-service teachers in the inclusion of Aboriginal experiences and perspectives. Elders' presence in the classroom, as previous research has explicated, is a powerful means of disrupting the ways students think about themselves and their province (Tupper \& Cappello, 2008). Further, it is important to remember that these students are preservice teacher candidates and as such, are always grappling with the question of how, regardless of whether they are in their first year or fourth year of teacher education. Students' claims of not knowing how' to implement treaty education, or the fear of making a mistake, suggests that ignorance is used as an epistemological position to protect their settler identities 
and to divest themselves of the responsibility to meaningfully engage with treaties and the treaty relationship.

\section{Ignorance as an Epistemological Position}

More broadly, and extending the earlier discussion regarding the role of curriculum in maintaining dominant knowledge systems, including settler identities, it is essential in the context of this research, to consider the ways in which curricula in/form epistemologies of ignorance, and in particular, white ignorance, which is itself a product of white normativity. Charles Mills (2007) writes that,

white normativity manifests itself in a white refusal to recognize the long history of structural discrimination that has left whites with the differential resources they have today, and all of its consequent advantages in negotiating opportunity structures If originally whiteness was race, then now it is racelessness, an equal status and a common history in which we have all shared, with white privilege being conceptually erased. (p. 28)

The concern that Canadians know little about the history of treaties and the treaty relationship despite their foundational importance is supported by the students' responses to all four of the anecdotal questions, and can be better understood using Mill's notion of white normativity and white ignorance. For example, if attention were to be paid to treaties and the treaty relationship, then the frontier myth of Canadian history subscribed to by many Canadians could no longer hold true. The frontier myth is part of a collective social memory of the past, but is also reflective of "collective amnesia" which Mills (2007) argues are inseparable "insofar as memory is necessarily selective - out of the infinite sequence of events, some trivial, some momentous, we extract what we see as the crucial ones and organize them into an overall narrative” (p.29). For white collective social memory, it is necessary to extract a narrative of frontier wilderness, of settling the land, rather than a narrative of settler invaders, or even of agreeing to share the land with First Nations people through the signing of the numbered treaties in the first place. This is essential to how we imagine ourselves as Canadians and to our settler identities.

In Saskatchewan, frontier myths constitute the collective story of the past imagined and produced primarily through the foundational story of the pioneer, rather than through the story of treaties (Mulholland, 2006 \& 2009; Wall, 2007). This social memory is "inscribed in textbooks, generated and regenerated in ceremonies and official holidays, concretized in statues, parks and monuments” (Mills, 2007, p. 29). And it is certainly evident in the students' responses to and (mis)understandings of treaties and the treaty relationship, the ease with which racist comments were offered up in each of the four questions, and the extent to which students failed to articulate/ connect the importance of treaties to their own social and economic privileges. Treaty education has the potential to challenge and even disrupt white normativity through the counter stories of the past and present it offers. White ignorance is "a form of not knowing (seeing wrongly), resulting from the habit of erasing, dismissing, distorting, and forgetting” the lives and experiences of Aboriginal people (Bailey, 2007, p. 85). It creates the conditions for students to have minimal encounters with knowledge and understandings essential to the mandate for treaty education, born out by the research data. 
Along with theories of white normativity, strategic ignorance also offers insight into students' responses. To be clear, strategic ignorance is employed here differently from the way it has been used by Alison Bailey (2007), who articulates strategic ignorance as a tool for people of colour in the United States to engage in acts of resistance. In the context of this research, strategic ignorance is also understood to be a tool of resistance, but in this case, it is resistance to meaningful engagement with the foundational importance of treaties and the treaty relationship. Here, strategic ignorance is used to theorize the students' responses to the four anecdotal questions. Specifically, the claim that no one has told students how to implement treaty education, although they know they need to do it, is a form of strategic ignorance. It suggests that teaching about treaties and the treaty relationship is outside of the processes and pedagogies students have become familiar with in their teacher education program. Through their expressions of concern, students may appear to be supportive of treaty education; however, their concern must be read differently. Additionally, by evoking the phrase "we are all treaty people" students are able to strategically protect their ignorance, and thus, their settler identities. The ability to call up the phrase divests many of them from the responsibility, the imperative, to unpack its meaning. They remain ignorant of how white privilege has been produced through treaties, using the phrase to strategically mask their ignorance while protecting their privilege.

\section{Conclusion}

Given the distressingly limited (though not surprising) understanding of the foundational importance of treaties and the treaty relationship reflected in the students' responses to the four anecdotal questions, what role must faculties of education, and specifically the Faculty of Education at the University of Regina, play in supporting beginning teachers to meaningfully engage with the mandate for treaty education? First, faculty members must carefully consider the ways in which our own pedagogies and course content either reproduce settler identities or work to disrupt them (or in some cases both). On a more basic level, recognizing and accounting for our students' (and our own) (mis)understandings of treaties and the treaty relationship creates opportunities throughout the program to work on behalf of treaty education. We cannot assume that students will have had meaningfully engagement with treaty education in their K-12 schooling, or that Indigenous Studies classes are the sites for this work to be done. Rather, as Epp (2008) writes,

Instead of posing the question about reconciliation as a matter of what 'they' [First Nations] want - recognition, compensation, land - and what 'we' can live with, the subject under closest scrutiny becomes 'ourselves'. In other words, the subject is not the 'Indian problem' but the 'settler' problem. (p. 126)

Thus, a more challenging aspect of this work requires focus on the "settler" problem and the naming of strategic ignorance when it is used by students (and colleagues). It also necessitates that we resist discourses of pastoral care, utilized out of concern for our students' feelings and their level of comfort in our classes (Dion, 2009). When we worry about how preservice teachers will respond to our interventions, and act on this worry by lessening the degree to which we disrupt settler identities through counter narratives, then we remain complicit in white normativity. Instead, the creation of discomfort/disruption in teacher education spaces should be viewed as not only an essential condition for (white) preservice teachers, but also for teacher 
educators. We must work alongside our students to reveal and unpack settler identities. This is the hard and necessary work of reconciliation. This is the imperative of treaty education. 


\section{References}

Apple. M. (1990). Ideology and curriculum. New York: Routledge.

Apple, M. (1996). Cultural politics and education. New York: Teachers College Press.

Bailey, A. (2007). Strategic ignorance. In S. Sullivan \& N. Tuana (Eds.), Race and epistemologies of ignorance (pp. 77-94). New York: SUNY Press.

Battiste, M., \& Semaganis, H. (2002). First thoughts on First Nations citizenship: Issues in education. In Y. Hebert (Ed.), Citizenship in transformation in Canada (pp. 93-111). Toronto: University of Toronto Press.

Bell, D. (1987). And we are not saved: The elusive quest for racial justice. New York: Basic Books.

Boyatzis, R. (1998). Transforming qualitative information: Thematic analysis and code development. Thousand Oaks, CA: Sage.

Cappello, M., \& Tupper, J. (2006). Aboriginal knowledge and perspectives: Identifying, delivering and assessing best practices with middle years students. Regina: Saskatchewan Instructional Development and Research Unit (SIDRU).

Carr, P.R., \& Lund, D.E. (Eds.) (2007). The great white North? Exploring whiteness, privilege and identity in education. Rotterdam: Sense Publishers.

Castagano, A.E., \& McKinley Jones Brayboy, B. (2008). Culturally responsive schooling for Indigenous youth: A review of the literature. Review of Educational Research, 78(4), 941993.

Chambers, C. (2006). "The land is the best teacher I have ever had”: Places as pedagogy for precarious times. Journal of Curriculum Theorizing, 22(3), 27-37.

Chandler, P. T. (2010). Critical race theory and social studies: Centering the Native American experience. Journal of Social Studies Research, 34(1), 29-58.

Creswell, J.W. (2005). Educational research: Planning, conducting, and evaluating quantitative and qualitative research. (2nd ed.). New Jersey: Pearson/Merrill Prentice Hall.

Crenshaw, K., Gotanda, N., Peller, G., \& Thomas, K. (Eds.). (1995). Critical race theory: The key writings that formed the movement. New York: New Press.

Crosland Nebeker, K. (1998). Critical race theory: A white graduate student's struggle with this growing area of scholarship. Qualitative Studies in Education, 11(1), 25-41. 
Delgado, R. (1989). Storytelling for oppositionists and others: A plea for narrative. Michigan Law Review, 87, 2411-2441.

Delgado, R. (1990). When a story is just a story: Does voice really matter? Virginia Law Review, 76, 95-111.

Delgado, R., \& Stefancic, J. (2001). Critical race theory: An introduction. New York: New York University Press.

Dion, S. (2009). Braiding histories: Learning from Aboriginal people's experiences and perspectives. Vancouver: UBC Press.

Dixson, A. D., \& Rousseau, C.K. (2006a). Critical race theory in education: All God's children got a song. New York: Routledge.

Dixson, A. D., \& Rousseau, C.K. (2006b). And we are still not saved: Critical race theory in education ten years later. In A.D. Dixson \& C.K. Rousseau (Eds.), Critical race theory in education: All God's children got a song (pp. 31-65). New York: Routledge.

Donald, D. T. (2009). The pedagogy of the fort: Curriculum, Aboriginal-Canadian relations, and Indigenous métissage. Unpublished doctoral dissertation, University of Alberta.

Earick, M.E. (2009). Racially equitable teaching: Beyond the whiteness of professional development for early childhood educators. New York: Peter Lang.

Epp, R. (2008). We are all treaty people: Prairie essays. Edmonton: University of Alberta Press.

Fereday, J., \& Muir-Cochrane, E. (2006). Demonstrating rigor using thematic analysis: A hybrid approach of inductive and deductive coding and theme development. International Journal of Qualitative Methods, 5(1), 1-11.

Furniss, E. (1999). The burden of history: Colonialism and the frontier myth in a rural Canadian community. Vancouver: UBC Press.

Gillborn, D. (2006). Critical race theory beyond North America: Toward a trans-Atlantic dialogue on racism and antiracism in educational theory and praxis. In A.D. Dixson \& C.K. Rousseau (Eds.), Critical race theory in education: All God's children got a song (pp. 241265). New York: Routledge.

Grant, A., \& Gillespie, L. (1993). Joining the circle: A practitioners' guide to responsive education for Native students. Charleston, WV: ERIC Clearinghouse on Rural Education and Small Schools.

Grumet, M. R. (1981). Restitution and reconstruction of educational experience: An autobiographical method for curriculum theory. In M. Lawn \& L. Barton (Eds.), Rethinking curriculum studies: A radical approach (pp. 115-130). London: Croom Helm. 
Howard, T. (2003). The Dis(g)race of the social studies: The need for racial dialogue in the social studies. In G. Ladson-Billings (Ed.), Critical race theory perspectives on the social studies: The profession, policies, and curriculum. Connecticut: Information Age Publishing.

Kailin, J. (2002). Antiracist education: From theory to practice. Lanham, MD: Rowan and Littlefield.

Ladson-Billings, G. (1998). Just what is critical race theory and what's it doing in a nice field like education? Qualitative Studies in Education, 11(1), 7-24.

Leonardo, Z. (2005). Critical pedagogy and race. New York: Wiley-Blackwell.

Littlejohn, C. (2006). The schooling of First Nation and Métis children in Saskatchewan schools to 1960 . In B. Noonan, D. Hallman, \& M. Scharf (Eds.), A history of education in Saskatchewan: Selected readings (pp. 63-86). Regina, SK: Canadian Plains Research Center.

Loewen, J. W. (2007). Lies my teacher told me: Everything your American history textbook got wrong. New York: The New Press.

Martin Alcoff, L. (2007). Epistemologies of ignorance. In S. Sullivan \& N. Tuana (Eds.), Race and epistemologies of ignorance (pp. 39-58). New York: SUNY Press.

Marx, S., \& Pennington, J. (2003). Pedagogies of critical race theory: Experimentation with white preservice teachers. Qualitative Studies in Education, 16(1), 91-110.

Miller, J.R. (2009). Compact, contract, covenant: Aboriginal treaty-making in Canada. Toronto: University of Toronto Press.

Mills, C. (2007). White ignorance. In S. Sullivan \& N. Tuana (Eds.), Race and epistemologies of ignorance (pp. 11-38). New York: SUNY Press.

Mulholland, V. (2006). Conscious of my fictions: A postcolonial reading of the autobiography of a Saskatchewan English teacher. Unpublished doctoral dissertation. Regina: University of Regina.

Mulholland, V. (2009). And carry on as though nothing happened. In P.J. Lewis \& J. Tupper (Eds.), Challenges bequeathed: Taking up the challenges of Dwayne Huebner (pp. 99-114). Rotterdam: Sense Publishers.

Omi, M., \& Winant, H. (1994). Racial formation in the United States: From the 1960s to the 1990s (2nd ed.). Boston: Routledge Kegan Paul.

Office of the Treaty Commissioner (2008). Treaty essential learnings: We are all treaty people. Saskatoon: OTC. 
Parker, L. (1998). “Race is...race ain't”: An exploration of the utility of critical race theory in qualitative research in education. Qualitative Studies in Education, 11(1), 43-55.

Parker, L., \& Lynn, M. (2002). What's race got to do with it? Critical race theory's conflicts with and connections to qualitative research methodology and epistemology. Qualitative Inquiry, 8(1), 7-22.

Pinar, W.F. (2004). What is curriculum theory? London: Lawrence Erlbaum Associates.

Rains, F. V. (2006). The color of social studies: A post-social studies reality check. In E.W. Ross (Ed.), The social studies curriculum: Purposes, problems and possibilities, (pp. 137-156). Albany: State University of New York Press.

Ralston Saul, J. (2008). A fair country: Telling truths about Canada. Toronto: Viking Canada.

Schick, C., \& St. Denis, V. (2005). Troubling national discourses in anti-racist curricular planning. Canadian Journal of Education, 28(3), 295-317.

Schumacher, S., \& McMillan, J. H. (1993). Research in education: A conceptual approach (3rd ed.). New York: HarperCollins.

Solórzano, D.G., \& Yosso, T.J. (2009). Critical race methodology: Counter story-telling as an analytical framework for educational research. In E. Taylor, D. Gillborn, \& G. LadsonBillings (Eds.), Foundations of critical race theory in education (pp. 131-147). New York: Routledge.

Solórzano, D.G., \& Yosso, T.J. (2002). Critical race methodology: Counter-storytelling as an analytical framework for education research. Qualitative Inquiry, 8(1), 23-44.

Sullivan, S. \& Tuana, N. (2007). Race and epistemologies of ignorance. New York: SUNY.

St. Denis, V. (2007). Aboriginal education and anti-racist education: Building alliance across cultural and racial identity. Canadian Journal of Education, 30(4), 1068-1092.

Tate, W.F. (1997). Critical race theory and education: History, theory, and implications. Review of Research in Education, 22, 195-247.

Tate, W. F. (1999). Conclusion. In L. Parker et al. (Eds.), Race is...race isn't: Critical race theory and qualitative studies in education (pp. 251-271). Boulder, CO: Westview.

Tupper, J., \& Cappello, M. (2008). Teaching treaties as (un)usual narratives: Disrupting the curricular commonsense. Curriculum Inquiry, 38(5), 559-578.

Wall, B. (2007). Hope beats fear. Retrieved from http://www.saskparty.com/multimedia/videos/hope-beats-fear 
Willinsky, J. (1998). Learning to divide the world: Education at empire's end. Minneapolis, MN: University of Minnesota Press.

Wright, R. (2008). What is America: A short history of the new world order. Toronto: Vintage Canada. 